\title{
Front Matter: Volume 6413
}

, "Front Matter: Volume 6413," Proc. SPIE 6413, Smart Materials IV, 641301 (16 January 2007); doi: 10.1117/12.724275

SPIE Event: SPIE Smart Materials, Nano- and Micro-Smart Systems, 2006, SPIE. Adelaide, Australia 


\title{
PROCEEDINGS OF SPIE
}

\section{Smart Materials IV}

\author{
Nicolas H. Voelcker \\ Chair/Editor
}

\section{1-13 December 2006 \\ Adelaide, Australia}

Sponsored and Published by

SPIE-The International Society for Optical Engineering

Cosponsored by

Australian Government Department of Defence, Defence Science and Technology Organisation (Australia)

Office of Naval Research through the Global Office of Naval Research Science and Technology (USA)

Air Force Office of Scientific Research through the Asian Office of Aerospace Research and Development (USA and Japan)

COSNet-ARC Complex Open Systems Research Network (Australia)

Australian Research Council Nanotechnology Network (Australia)

Volume 6413

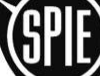


The papers included in this volume were part of the technical conference cited on the cover and title page. Papers were selected and subject to review by the editors and conference program committee. Some conference presentations may not be available for publication. The papers published in these proceedings reflect the work and thoughts of the authors and are published herein as submitted. The publisher is not responsible for the validity of the information or for any outcomes resulting from reliance thereon.

Disclaimer: The support provided for the conference by the co-sponsors is not intended as an endorsement of the contents of anything in these proceedings. Specifically, DSTO support is not intended to express or imply endorsement by the Australian Commonwealth Government; AFOSR/AOARD support is not intended to express or imply endorsement by the U.S. Federal Government; ONR Global support is not intended to express or imply endorsement by the U.S. Federal Government; COSNet support is not intended to express or imply endorsement by the Australian Research Council (ARC) or the Australian Commonwealth Government; ARC Nanotech Network support is not intended to express or imply endorsement by the Australian Research Council (ARC) or the Australian Commonwealth Government.

Please use the following format to cite material from this book:

Author(s), "Title of Paper," in Smart Materials IV, edited by Nicolas H. Voelcker, Proceedings of SPIE Vol. 6413 (SPIE, Bellingham, WA, 2007) Article CID Number.

ISSN 0277-786X

ISBN 9780819465214

Published by

SPIE-The International Society for Optical Engineering

P.O. Box 10, Bellingham, Washington 98227-0010 USA

Telephone 1 360/676-3290 (Pacific Time) · Fax 1 360/647-1445

http://www.spie.org

Copyright $@$ 2007, The Society of Photo-Optical Instrumentation Engineers

Copying of material in this book for internal or personal use, or for the internal or personal use of specific clients, beyond the fair use provisions granted by the U.S. Copyright Law is authorized by SPIE subject to payment of copying fees. The Transactional Reporting Service base fee for this volume is $\$ 15.00$ per article (or portion thereof), which should be paid directly to the Copyright Clearance Center (CCC), 222 Rosewood Drive, Danvers, MA 01923. Payment may also be made electronically through CCC Online at http://www.copyright.com. Other copying for republication, resale, advertising or promotion, or any form of systematic or multiple reproduction of any material in this book is prohibited except with permission in writing from the publisher. The CCC fee code is 0277-786X/07/\$15.00.

Printed in the United States of America. 


\title{
Contents
}

\author{
vii Conference Committee \\ ix Introduction \\ xi Symposium Sponsors \\ COMPOSITE NANOMATERIALS \\ 641302 Anisotropic surface roughness enhances the bending response of ionic polymer-metal \\ composite (IPMC) artificial muscles [6413-02] \\ B. L. Stoimenov, RIKEN (Japan); J. M. Rossiter, RIKEN (Japan) and Univ. of Bristol (United \\ Kingdom); T. Mukai, RIKEN (Japan) \\ 641303 Plasma modified carbon surfaces for supporting sensor architectures [6413-03] \\ J. S. Quinton, A. Deslandes, A. Barlow, J. G. Shapter, Flinders Univ. (Australia)

\section{NANOMATERIAL-BASED SENSORS} \\ 641304 Three-dimensional network of ZnO tetrapods for use in gas sensing (Invited Paper) \\ [6413-04] \\ J.-J. Delaunay, K. Yanagisawa, T. Nishino, I. Yamada, The Univ. of Tokyo (Japan) \\ 641305 Modeling of active fiber composite for delamination sensing [6413-05] \\ P. J. Guruprasad, Texas A\&M Univ. (USA); A. K. Tamrakar, D. Harursampath, Indian Institute \\ of Science, Bangalore (India) \\ 641306 Highly reliable advanced grid structures (HRAGS) for aircraft structures using multi-point \\ FBG sensor [6413-06] \\ H. Takeya, K. Sekine, M. Kume, T. Ozaki, Mitsubishi Electric Corp. (Japan); N. Takeda, The \\ Univ. of Tokyo (Japan); N. Tajima, R\&D Institute of Metals and Composites for Future \\ Industries (Japan)
}

\footnotetext{
Pagination: Proceedings of SPIE follow an e-First publication model, with papers published first online and then in print and on CD-ROM. Papers are published as they are submitted and meet publication criteria. A unique, consistent, permanent citation identifier (CID) number is assigned to each article at the time of the first publication. Utilization of CIDs allows articles to be fully citable as soon they are published online, and connects the same identifier to all online, print, and electronic versions of the publication.

SPIE uses a six-digit CID article numbering system in which:

- The first four digits correspond to the SPIE volume number.

- The last two digits indicate publication order within the volume using a Base 36 numbering system employing both numerals and letters. These two-number sets start with 00, 01, 02, 03, 04, 05, 06, 07, 08, 09, 0A, 0B ... 0Z, followed by 10-1Z, 20-2Z, etc.

The CID number appears on each page of the manuscript. The complete citation is used on the first page, and an abbreviated version on subsequent pages.
} 
641308 Low-temperature processing of lead zirconate titanate thin films by $28 \mathrm{GHz}$ microwave irradiation for MEMS application [6413-08]

Z. J. Wang, H. Kokawa, H. Takizawa, Tohoku Univ. (Japan); M. Ichiki, R. Maeda, National Institute of Advanced Industrial Science and Technology (Japan)

641309 Analysis of constrained piezoelectric thin film sensor [6413-09]

R. Ali, S. Gopalakrishnan, Indian Institute of Science, Bangalore (India)

BIONANOTECHNOLOGY I

64130B Microarrays for the evaluation of cell-biomaterial surface interactions (Invited Paper) [6413-11]

H. Thissen, CSIRO Molecular and Health Technologies (Australia) and CSIRO Food Futures Flagship (Australia); G. Johnson, G. McFarland, CSIRO Molecular and Health Technologies (Australia); B. C. H. Verbiest, CSIRO Molecular and Health Technologies (Australia) and Eindhoven Univ. of Technology (Netherlands); T. Gengenbach, CSIRO Molecular and Health Technologies (Australia); N. H. Voelcker, CSIRO Food Futures Flagship (Australia) and Flinders Univ. (Australia)

64130C A platform for the advanced spatial and temporal control of biomolecules [6413-12] A. L. Hook, Flinders Univ. (Australia) and CSIRO Molecular and Health Technologies (Australia); H. Thissen, CSIRO Molecular and Health Technologies (Australia); J. P. Hayes, MinifAB (Australia); N. H. Voelcker, Flinders Univ. (Australia)

64130D Radio frequency controlled microvalve for biomedical applications [6413-13]

D. W. Dissanayake, A. C. Tikka, S. F. Al-Sarawi, D. Abbott, Univ. of Adelaide (Australia)

\section{BIONANOTECHNOLOGY II}

64130 E Nanomechanical properties of supported lipid bilayers studied by force spectroscopy (Invited Paper) [6413-14]

S. Garcia-Manyes, G. Oncins, F. Sanz, Univ. de Barcelona (Spain)

64130F Hybrid organic-inorganic nanoparticles: controlled incorporation of gold nanoparticles into virus-like particles and application in surface-enhanced Raman spectroscopy [6413-15]

M. Niebert, J. Riches, M. Howes, C. Ferguson, R. G. Parton, A. P. J. Middelberg, L. Rintoul, P. M. Fredericks, Queensland Univ. of Technology (Australia)

\section{ACTIVE MATERIALS}

$64130 \mathrm{G}$ Responsive interfaces grafted with polyelectrolyte or polyampholyte (Invited Paper) [6413-16]

Y. Tran, S. Sanjuan, N. Pantoustier, P. Perrin, Lab. de Physico-chimie des Polymères et des Milieux Dispersés, ESPCl (France) 
64130K Three-dimensional deposition of silicon from silicate glass with dispersed metallic aluminum by a femtosecond laser (Invited Paper) [6413-21]

K. Miura, Y. Shimotsuma, M. Sakakura, S. Kanehira, M. Hamabe, K. Hirao, Kyoto Univ. (Japan)

64130L Laser interference deposition of silver nanoparticles on glass [6413-22]

F. Funabiki, T. Yano, S. Shibata, Tokyo Institute of Technology (Japan)

$64130 \mathrm{M}$ Nano-sized modification of transparent materials using femtosecond laser irradiation [6413-23]

S. Kanehira, K. Miura, K. Fujita, K. Hirao, Kyoto Univ. (Japan)

\section{POSTER SESSION}

641300 Measurement of mechanically induced luminescence from microparticles [6413-26] T. Koga, K. Sakai, S. Maehara, N. Terasaki, Y. Imai, C. N. XU, National Institute of Advanced Industrial Science and Technology (Japan)

64130P Mechanical response of a low-temperature sintered body consisting of submicron gold particles [6413-27]

T. Shibutani, Q. Yu, Y. Fujisawa, M. Shiratori, Yokohama National Univ. (Japan); K. Tsurumi,

T. Ogashiwa, M. Miyairi, Tanaka Kikinzoku Kogyo K.K. (Japan)

64130Q Silica nanostructure formation from synthetic R5 peptide [6413-30]

I. Tajuddin, Haluoleo Univ. (Indonesia); N. Voelcker, J. Mitchell, Flinders Univ. (Australia)

64130R Application of nanostructured biochips for efficient cell transfection microarrays [6413-31] Y. Akkamsetty, Flinders Univ. (Australia); A. L. Hook, Flinders Univ. (Australia) and CSIRO Molecular and Health Technologies (Australia); H. Thissen, CSIRO Molecular and Health Technologies (Australia); J. P. Hayes, MiniFAB (Australia); N. H. Voelcker, Flinders Univ. (Australia)

$64130 \mathrm{~V}$ Fabrication of embedded conductive layer in polymer by plasma immersion ion implantation [6413-36]

P. C. T. Ha, Z. J. Han, B. K. Tay, Nanyang Technological Univ. (Singapore)

64130X Preparation of SMART wound dressings based on colloidal microgels and textile fibres [6413-39]

V. J. Cornelius, N. Majcen, M. J. Snowden, J. C. Mitchell, Univ. of Greenwich (United Kingdom); B. Voncina, The Univ. of Maribor (Slovenia)

64130Y The use of colloidal microgels for the controlled delivery of proteins and peptides [6413-40] V. J. Cornelius, M. J. Snowden, J. C. Mitchell, Univ. of Greenwich (United Kingdom) 
641302 A novel surface modification approach for protein and cell microarrays [6413-42] M. D. Kurkuri, Flinders Univ. (Australia); C. Driever, CSIRO Molecular and Health Technologies (Australia); H. W. Thissen, CSIRO Molecular and Health Technologies (Australia) and CSIRO Food Futures Flagship (Australia); N. H. Voelcker, Flinders Univ. (Australia), CSIRO Molecular and Health Technologies (Australia), and CSIRO Food Futures Flagship (Australia)

Author Index 


\title{
Conference Committee
}

\author{
Symposium Chairs
}

Joe G. Shapter, Flinders University of South Australia (Australia)

Vijay K. Varadan, University of Arkansas (USA)

Derek Abbott, The University of Adelaide (Australia)

Conference Chair

Nicolas H. Voelcker, Flinders University of South Australia (Australia)

Conference Cochairs

Alan R. Wilson, Defence Science and Technology Organisation (Australia)

Hans J. Griesser, University of South Australia (Australia)

Neville V. Richardson, University of St. Andrews (United Kingdom)

Fausto Sanz, Universitat de Barcelona (Spain)

Program Committee

Frank Caruso, The University of Melbourne (Australia)

Giuseppe Cavallaro, Commonwealth Scientific and Industrial Research Organisation (Australia)

Jason P. Hayes, MiniFAB Pty Ltd. (Australia)

Sunil Kumar, University of South Australia (Australia)

Max Lu, The University of Queensland (Australia)

David Mainwaring, Royal Melbourne Institute of Technology (Australia)

Thomas Maschmeyer, The University of Sydney (Australia)

Anton P. J. Middelberg, The University of Queensland (Australia)

Colin Raston, The University of Western Australia (Australia)

Helmut W. Thissen, Commonwealth Scientific and Industrial Research

Organisation (Australia)

Wei-Bor Tsai, National Taiwan University (Taiwan)

Terence W. Turney, Commonwealth Scientific and Industrial Research

Organisation (Australia)

Robert B. Yates, Gillette Management Inc. (United Kingdom)

\section{Session Chairs}

1 Composite Nanomaterials

Sunil Kumar, University of South Australia (Australia)

2 Nanomaterial-based Sensors

Alan R. Wilson, Defence Science and Technology Organisation (Australia) 
Piezoelectrics

Neville V. Richardson, University of St. Andrews (United Kingdom)

4 Bionanotechnology I

Nicolas H. Voelcker, Flinders University of South Australia (Australia)

5 Bionanotechnology II

Helmut W. Thissen, Commonwealth Scientific and Industrial Research Organisation (Australia)

6 Active Materials

Neville V. Richardson, University of St. Andrews (United Kingdom)

$7 \quad$ Organic Thin Films

Nicolas H. Voelcker, Flinders University of South Australia (Australia)

8 Laser-assisted Nanofabrication

Jason P. Hayes, MiniFAB Pty Ltd. (Australia) 


\title{
Introduction
}

The conference Smart Materials IV was part of the SPIE International Symposium on Smart Materials, Nano- and Micro-Smart Systems, held at Adelaide University, Adelaide, Australia, on 11-13 December 2006.

This multidisciplinary conference covered a wide range of topical smart materials issues including nanomaterial-based sensors, composite nanomaterials, stimuliresponsive materials, piezoelectrics, organic thin films, laser-assisted nanofabrication, electroactive polymers, surface modification, bio-inspired materials, and many more.

Our thanks go to the symposium chairs, first and foremost Associate Professor Joe Shapter, but certainly also Professor Vijay Varadan and Professor Derek Abbott, for bringing their organizational talents to bear to this thoughtfully arranged symposium. Special thanks go to the international program committee for their support in reviewing papers. We thank SPIE's technical programs and proceedings staff for their skillful organizing and editing work. We appreciated greatly the co-sponsorship by the Defence Science and Technology Organisation, the Office of Naval Research, and the Air Force Office of Scientific Research, as well as the Australian Nanotechnology Network and the Complex Open Systems Research Network of the Australian Research Council.

All manuscripts in this conference were peer-reviewed by two or more members of the international program committee. The manuscripts were judged on the basis of originality, substance, technical quality, and significance. The review outcomes have been provided to the authors.

Finally, our appreciation must go to the authors for sharing their work and ideas. The enthusiasm and interaction shown during the conference period among authors and attendees has rewarded us greatly.

\author{
Nicolas H. Voelcker \\ Alan Wilson \\ Neville Richardson \\ Fausto Sanz
}


Downloaded From: https://www.spiedigitallibrary.org/conference-proceedings-of-spie on 26 Apr 2023

Terms of Use: https://www.spiedigitallibrary.org/terms-of-use 


\section{Major Co-sponsor}

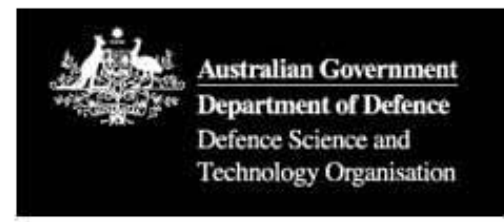

\section{Co-sponsors}
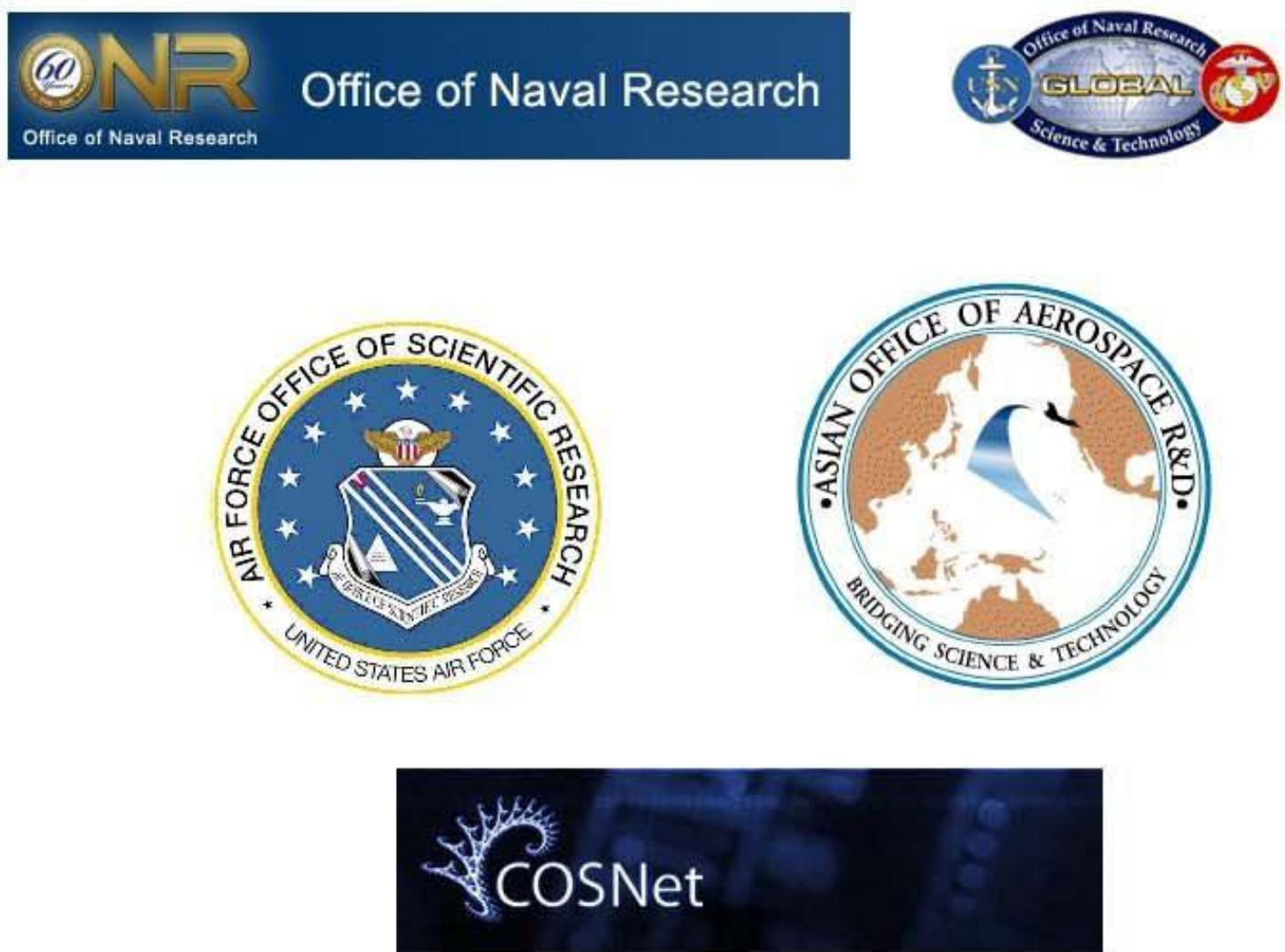

ARC Complex Open Systems Research Network

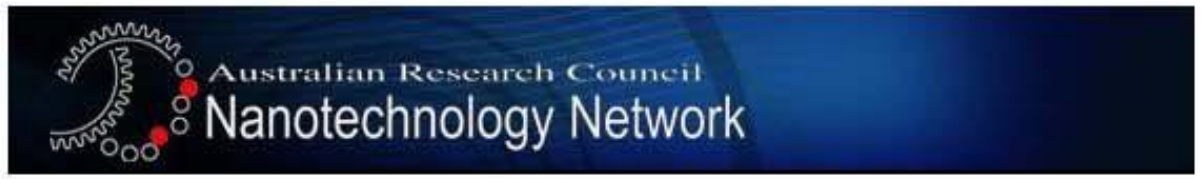

We wish to thank the co-sponsors for their contribution to the success of the conference:

Defence Science and Technology Organisation (DSTO)

Air Force Office of Scientific Research, Asian Office of Aerospace Research and Development

Office of Naval Research Global

ARC Complex Open Systems Research Network

ARC Nanotechnology Network 
Downloaded From: https://www.spiedigitallibrary.org/conference-proceedings-of-spie on 26 Apr 2023

Terms of Use: https://www.spiedigitallibrary.org/terms-of-use 